\title{
Performance of Malaysian Insurance Companies Using Data Envelopment Analysis
}

\author{
Ng Jia Bao ${ }^{1}$, Rohaizan Ramlan ${ }^{2}$, Fazeeda Mohamad ${ }^{3}$, Azlina Md Yassin ${ }^{4}$ \\ ${ }^{1,2,4}$ Faculty of Technology Management and Business, Universiti Tun Hussein Onn Malaysia, Malaysia \\ ${ }^{3}$ Faculty of Industrial Management, Universiti Malaysia Pahang, Malaysia
}

\section{Article Info \\ Article history: \\ Received Apr 27, 2018 \\ Revised May 28, 2018 \\ Accepted Jun 11, 2018}

\section{Keywords:}

Data Envelopment Analysis (DEA)

Local insurances companies

Performance measurement

\begin{abstract}
The purpose of this study is to evaluate the performance of the local insurance in Malaysia for the period 2014-2015. The major challenge in the insurance industry is increasing competition in this market. Besides that, problematic in performance measurement to evaluate performance is another challenge in insurance industry. 24 local insurance companies involved in this study using quantitative method of Data Envelopment Analysis (DEA) output-orientation CCR model. This study utilizes three inputs and three outputs; operating expenses, equity capital and commission as well as net premium, net investment income, and net incurred claim. The secondary data sources were derived from official data of local insurance companies' annual report respectively. The DEA-Solver-LV version 8 tools were used to analyze the data that have been collected to evaluate the performance of local insurance company. This DEA model allows integration of the performance for the insurance companies and provides management overall performance evaluation. The results showed that there are 8 efficient companies in 2014 and 9 efficient companies in 2015. The average efficiency score in 2014 was increased from $78.9 \%$ to $79.1 \%$ in 2015 . The findings from this study will benefit the insurance associations in Malaysia, management of insurances companies and policy makers.
\end{abstract}

Copyright $@ 2018$ Institute of Advanced Engineering and Science. All rights reserved.

\section{Corresponding Author:}

Azlina Md Yassin,

Faculty of Technology Management and Business,

Universiti Tun Hussein Onn Malaysia, Malaysia.

Email: Rohaizan@uthm.edu.my

\section{INTRODUCTION}

Insurance is one of the largest, most important of financial services in Malaysia [1] and regarded as a growing industry with significant progress and continues to play the role of socio-economic importance in the economy [2]. Malaysia's insurance sector accounts for around 6 percent of financial sector assets [3], commonly divided into life and general insurance. Generally, insurance services can be classified into medical and health insurance, motor insurance, personal accident insurance, term life insurance, critical illness insurance, fire and homeowner's insurance and others services. A total of 44 insurance companies were found in Malaysia where 26 of them are local companies and another 18 are foreign companies [4].

The main challenge facing the insurance industry in the future is to increase competition from traders of the global trend of consolidation and specialization to create a larger, more advanced international insurance company and focus on the core competency field[4].For example, the rapid growth of competition among insurers in the industrial and non-insurance institutions such as banks, mutual funds and others, as well as the dynamic changes in technology insurance companies must modify their products to gain a competitive advantage[5]. 
A liberalisation plan for Malaysia's insurance sector was announced by the government to increase the foreign equity participation threshold in insurance companies from $49 \%$ to $70 \%$ [6]. It allowed foreignregistered insurance companies set up branches in Malaysia, without any restrictions [7]. According to [4] the focus will continue to be given to the insurance sector's liberalization plan. This liberalisation plan has increased competition in this fragmented insurance sector [8], [9] mentioned that takaful and insurance operators had to push for innovative ideas to keep their growth momentum abreast with the increasingly competitive market, especially with the entrance of bigger multinational companies

In the competitive market, performance measurement in the insurance sector is becoming vital in contemporary business environment [10], since it will lead to the whole sector, it also will eventually led growth in overall economic prosperity [11]. According to [12], the measurement of insurance performance is mostly focused on the efficient frontier approach. This has been used widely to assess the efficiency levels as both approaches allow the use of multiple inputs and outputs from a sample of institutions to develop an efficiency frontier and evaluate the efficiency of a Decision Making Units (DMUs) relative to other DMUs in the sample. There are many studies have been done to measure the performance of insurance companies using DEA ([10]; [13]; [14]; [15] and [16]). Therefore, this study attempts to evaluate the performance of the local insurance companies in Malaysia for the year of 2014 and 2015 by using Data Envelopment Analysis (DEA) that has been widely used to compare performance across the individual firm. Furthermore, this study employed accounting data in the financial statement from annual report companies respectively to estimate a comparative ratio of weighted input and output for each company.

The appropriate choice of inputs and outputs play a major role in the study of efficiency using DEA. For the inputs, data were based on the literature survey consisting of three variables which are operation expenses, equity capital, and commission. Meanwhile, three outputs are net premium, net investment income, and net incurred as shown as Figure 1.

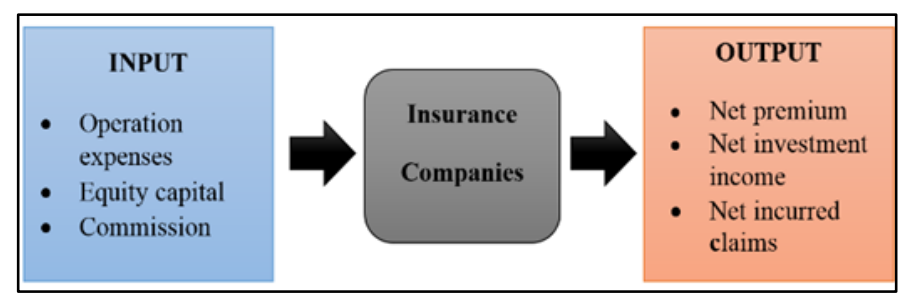

Figure 1. Input and Output variable and measurement

\section{RESEARCH METHOD}

This study has been conducted at local insurance companies in Malaysia. The secondary data sources derived entirely based on the annual report of the insurance companies respectively-for the year 2014 and 2015. A total of 44 companies were identified from Licensed Insurance Companies \& Takaful Operators list. However, this study focuses only 26 Local insurance companies in Malaysia. The collected data analyzed using DEA software "Learning Version" (DEA-Solver-LV version 8) to evaluate the operating efficiency of Malaysia insurers.

The first step in DEA is a determination of the DMU, which is the insurance company. Next step is to identify variable (input and output) and selecting a model. There are six variable for input and output as shown in Figure 1 also applying the CCR model (Cranes, Cooper, Rhodes) output-orientation that aims to maximize output using a set of input. Then, the collected data analyzed using DEA-Solver-LV version 8 to get the results.

\section{RESULTS AND ANALYSIS}

Two insurance companies were excluded from 26 selected local insurance companies because of missing information which are Danajamin Nasional Bhd and Sun Life Malaysia Takaful Bhd. Data were collected from the annual reports insurance companies' website respectively.

Table 1 shows ranking of local insurance companies over the period 2014 and 2015. There are eight companies which are AmMetLife Insurance Bhd, Hong Leong Assurance Bhd, MCIS Insurance Bhd, Etiqa Insurance Bhd, Etiqa Takaful Bhd, HSBC Amanah Takaful (M) Bhd, MAA Takaful Bhd, and Prudential BSN Takaful Bhd, maintained their ranking in efficiencies level over the period 2014 and 2015. Meanwhile, five companies the ranking of efficiency were decreased which are Sun Life Malaysia Assurance Bhd, 
Pacific \& Orient Insurance Co. Bhd, AmGeneral Insurance Bhd, AXA Affin General Insurance Bhd, and Berjaya Sompo Insurance Bhd. The most remarkable difference in the efficiency ranking of the local insurance companies within two years was Syarikat Takaful Malaysia Bhd. Their performance rose to 12th place in 2015 while it was in 19th place in 2014. In addition, Gibraltar BSN Life Bhd was inefficient in 2014, becomes efficient in 2015 and AmMetLife Takaful Bhd was ranked 13th in 2014, ranked 19th in 2015.

Table 1. Ranking of Local Insurance Companies Over the Period 2014 and 2015

\begin{tabular}{lcc}
\multicolumn{1}{c}{$\begin{array}{c}\text { Decision Making Unit } \\
\text { (DMUs) }\end{array}$} & $\begin{array}{c}2014 \\
\text { Ranking }\end{array}$ & $\begin{array}{c}2015 \\
\text { Ranking }\end{array}$ \\
\hline 1. AXA Affin Life Insurance Bhd. & 17 & 13 \\
2. AmMetLife Insurance Bhd. & 1 & 1 \\
3. Gibraltar BSN Life Bhd. & 9 & 1 \\
4. Hong Leong Assurance Bhd. & 1 & 1 \\
5. MCIS Insurance Bhd. & 1 & 1 \\
6. Sun Life Malaysia Assurance Bhd & 10 & 11 \\
7. AXA Affin General Insurance Bhd. & 15 & 16 \\
8. AmGeneral Insurance Bhd. & 14 & 15 \\
9. Berjaya Sompo Insurance Bhd. & 16 & 18 \\
10. Lonpac Insurance Bhd. & 18 & 17 \\
11. MPI Generali Insurans Bhd. & 22 & 22 \\
12. Pacific \& Orient Insurance Co. Bhd. & 12 & 14 \\
13. Progressive Insurance Bhd. & 23 & 23 \\
14. RHB Insurance Bhd. & 20 & 20 \\
15. Tune Insurance Malaysia Bhd. & 24 & 24 \\
16. Etiqa Insurance Bhd. & 1 & 1 \\
17. AmMetLife Takaful Bhd. & 13 & 19 \\
18. Etiqa Takaful Bhd. & 1 & 1 \\
19. HSBC Amanah Takaful (Malaysia) Bhd. & 1 & 1 \\
20. Hong Leong MSIG Takaful Bhd. & 21 & 21 \\
21. MAA Takaful Bhd. & 1 & 1 \\
22. Prudential BSN Takaful Bhd. & 1 & 1 \\
23. Syarikat Takaful Malaysia Bhd. & 19 & 10 \\
24. Takaful Ikhlas Bhd. & 11 & \\
\hline
\end{tabular}

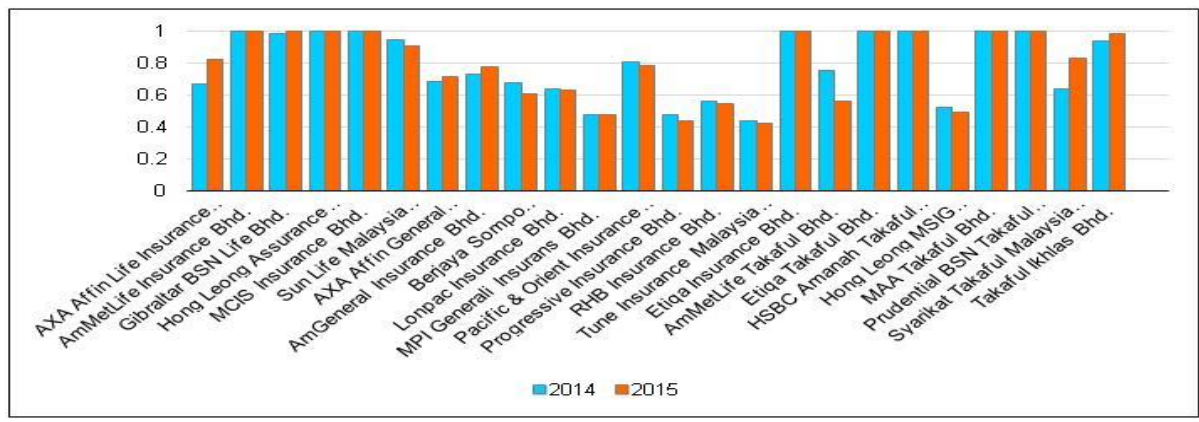

Figure 2. Summary evaluation of Local Insurance Companies over the period 2014 and 2015

Figure 2 illustrates the estimation of efficiency insurance companies in Malaysia. In the year 2014, eight local insurance companies are 100 percent efficient as compared to all other companies and in the year 2015, nine local insurance companies were found completely efficient at the best frontier as derive from overall efficiency scores. The average of the efficiency has been increased from $78.9 \%$ in 2014 to $79.1 \%$ in 2015. AmMeltLife Insurance Bhd, Hong Leong Assurance Bhd, MCIS Insurance Berhad, Etiqa Insurance Berhad, Etiqa Takaful Berhad, HSBC Amanah Takaful (Malaysia) Berhad, MAA Takaful Berhad and Prudential BSN Takaful Berhad are consistently efficient with efficiency score equal to one. Beside, there are few firms such as Hong Leong MSIG Takaful Berhad, Tune Insurance Malaysia Berhad, RHB Insurance Berhad, Progressive Insurance Berhad and MPI Generali Insurance Berhad which have been remained at the bottom ranking during the period. Gibraltar BSN Life Bhd was the companies inefficient in 2014, becomes efficient in 2015. In addition, the most remarkable difference in the efficiency score and ranking of the local insurance companies between the year 2014 and 2015 is that Syarikat Takaful Malaysia Bhd had increased from 63.36 percent to 83.22 percent. On the other hand, AmMetLife Takaful Bhd, changed the 
most in the reduction of efficiency score which is 26.01 percent, decreased from 75.47 percent to 55.84 percent.

Table 3 shows the percentage change in each of the input and output variable for inefficient local insurance companies in the year 2015. DEA efficiency measure whether local insurance companies can improve the performance, relative to the set of local insurance companies that being compared. Potential improvement shows the change in each input variable (output) the unit would have in order to become efficient. The slack variables and the target value (percentage change) for 100 percent efficiency insurance companies are zero. Therefore, all local insurance companies shows inefficiency since the DEA model has been unable to identify some feasible production point which can improve on some other input or output level. In addition, the target values (percentage change) of input and output for inefficient, banks along with potential addition in output and potential reduction in input. The potential improvement shows those areas of improvement in input-output activity required to put inefficient insurance companies onto the efficient frontier. For example the case of Tune Insurance Malaysia Bhd, a most inefficient bank in the sample require to reduce its equity capital input by 3.952 percent and increase its output net premium by 21.199 percent, net investment income 506.181 percent and net incurred income by 391.898 percent.

Moreover, the target value or the variable that required to improve on the efficient frontier determined using the similar ways for other inefficient banks. For instance, AXA Affin Life Insurance Bhd follow Hong Leong Assurance Bhd, Etiqa Takaful Bhd and HSBC Amanah Takaful (M) Bhd as role models and emulate their policies. Thus, there is further scope for increasing the output net premium, net investment income, and net incurred claim by 21.199 percent, 134.336 percent, and 21.199 percent respectively. The input management expenses for this company also required to be decreased to 42.202 percent. Likewise, Sun Life Malaysia Assurance Bhd can reduce its input equity capital by 44.369 percent and increase output net premium by 10.681 , net investment income by 14.791 percent, and net incurred claim by 21.199 percent while maintaining efficient level equivalent to that of its peers which are Hong Leong Assurance Bhd, Etiqa Takaful Bhd and HSBC Amanah Takaful (M) Bhd. AXA Affin General Insurance Bhd also required to increase their output to improve their performance which are net premium by 39.592 percent, net investment income by 251.371 percent and net incurred claim 48.076 percent according to the peer companies Etiqa Takaful Bhd and HSBC Amanah Takaful (M) Bhd. Similarly, by applying this method for all inefficient insurance company in each year, the improvement strategy be able to accomplish.

\section{CONCLUSION}

The empirical result shows that the efficiency performance of the local insurance companies increases as a whole during the period of 2014 and 2015. The average efficiency score in 2014 is $78.9 \%$ increased to $79.1 \%$ in the year 2015. Besides that, of the 24 local insurance companies, only 9 were efficient in the year 2015. Meanwhile, 15 local insurance companies have reported as inefficient since they were operating below the efficient frontier need to improve their performance in order to improve their profitability. In nut shell, the result shows the areas of inefficient local insurance companies are lagging behind and how be able to improve their performance to be better as their benchmark, who obtained efficiency score 1 .

Table 3. Percentage Change for Inefficient Local Insurance Companies in the Year 2015

\begin{tabular}{clccccccc}
\hline Code & Company name & $\begin{array}{c}\text { Efficiency } \\
\text { score (\%) }\end{array}$ & $\mathbf{X}_{\mathbf{1}}$ & $\mathbf{X}_{\mathbf{2}}$ & $\mathbf{X}_{\mathbf{3}}$ & $\mathbf{Y}_{\mathbf{1}}$ & $\mathbf{Y}_{\mathbf{2}}$ & $\mathbf{Y}_{\mathbf{3}}$ \\
\hline 1 & AXA Affin Life Insurance Bhd & 82.51 & -42.202 & 0 & 0 & 21.199 & 134.336 & 21.199 \\
6 & Sun Life Malaysia Assurance Bhd & 90.35 & 0 & -44.369 & 0 & 10.681 & 14.791 & 18.401 \\
7 & AXA Affin General Insurance Bhd & 71.64 & 0 & 0 & 0 & 39.592 & 251.371 & 48.076 \\
8 & AmGeneral Insurance Bhd & 77.45 & 0 & -29.118 & 0 & 29.122 & 204.152 & 61.413 \\
9 & Berjaya Sompo Insurance Bhd & 60.85 & 0 & -16.879 & 0 & 64.331 & 324.816 & 103.479 \\
10 & Lonpac Insurance Bhd & 63.25 & 0 & 0 & 0 & 58.114 & 385.693 & 177.599 \\
11 & MPI Generali Insurans Bhd & 47.62 & 0 & 0 & 0 & 109.987 & 345.417 & 212.51 \\
12 & Pacific \& Orient Insurance Co. Bhd & 78.36 & -7.747 & 0 & 0 & 27.611 & 126.518 & 27.611 \\
13 & Progressive Insurance Bhd & 43.53 & 0 & -40.957 & 0 & 129.73 & 220.145 & 152.227 \\
14 & RHB Insurance Bhd & 54.62 & 0 & 0 & 0 & 83.077 & 363.639 & 167.697 \\
15 & Tune Insurance Malaysia Bhd & 42.21 & 0 & -3.952 & 0 & 136.932 & 506.181 & 391.898 \\
17 & AmMetLife Takaful Bhd & 55.84 & -5.903 & 0 & 0 & 79.088 & 223.891 & 79.088 \\
20 & Hong Leong MSIG Takaful Bhd & 49.12 & 0 & -0.476 & 0 & 103.591 & 131.653 & 116.469 \\
23 & Syarikat Takaful Malaysia Bhd & 83.22 & -12.582 & 0 & 0 & 20.165 & 99.71 & 20.165 \\
24 & Takaful Ikhlas Bhd & 98.14 & -35.98 & 0 & 0 & 1.89 & 16.996 & 1.89 \\
& Average & $79.1 \%$ & $\mathbf{- 4 . 3 5 0 6}$ & $\mathbf{- 5 . 6 5 6 3}$ & $\mathbf{0}$ & $\mathbf{3 8 . 1 2 9 6}$ & $\mathbf{1 3 9 . 5 5 5}$ & $\mathbf{6 6 . 6 5 5 1}$ \\
\hline
\end{tabular}

Indonesian J Elec Eng \& Comp Sci, Vol. 11, No. 3, September 2018 : 1147 - 1151 


\section{REFERENCES}

[1] Lee Kam Hing. Introduction, A Matter of Risk Insurance in Malaysia 1826-1990, Nus Press Singapore. 2012: 2-3.

[2] Central Bank of Malaysia. Annual Insurance Statistics. 2015. Retrieved on March 7, 2016, from http://www.bnm.gov.my/index.php?ch=statistic\&pg=stats_insurance\&eId=box2\&lang=en\&ac=121

[3] International Monitory Fund. Malaysia Financial Sector Assesment Program. Report Number: 98.2014

[4] Central Bank of Malaysia. Financial Sector Blueprint 2011-2020. ISBN: 978-983-9586-47-3.

[5] Yakob, R., Yusop, Z., Radam, A., \& Ismail, N. (2011). Risk management efficiency of conventional life insurers and Takaful operators. Proceedings of 2nd International Conference on Mathematical Sciences. Kuala Lumpur. $2010 ; 1,830-849$

[6] BNM. (2009). Liberalisation of the financial sector. Retrieved May $3 \quad 2016$, from http://www.bnm.gov.my/index.php?ch=en_press\&pg=en_press_all\&ac=1817

[7] MRCB (2010). The General Insurance Industry of Malaysia: Performance and Prospects. Malaysian Rating Corporation Berhad. Retrieved May 1, 2016 from http://www.marc.com.my/index.php/marc-analytical-insights/550the-general-insurance-industry-of-malaysia-performance-a-prospect-july-2010/file

[8] Nourani M, Devadason ES, Kweh QL, Lu WM. Business excellence: the managerial and value-creation efficiencies of the insurance companies. Total Quality Management \& Business Excellence. 2017 Jun 7;28(7-8):879-96.

[9] The Star Online News. Insurers operating at higher costs likely to be affected by GST. Retrieved on March 6, 2016 from http://m.thestar.com.my/story.aspx?hl=Insurers+operating+at+higher+costs+likely+to+be+affected+by+GST\&sec= business\&id=\%7BACF1D250-12F1-411A-A7A5-872B144BA470\%7D

[10] Janjua PZ, Akmal M. A comparative analysis of economic efficiency of conventional and Islamic insura

[11] nce industry in Pakistan. Pakistan Business Review. 2015;17(1):21-44.

[12] Mehari D, Aemiro T. Firm specific factors that determine insurance companies'performance in ethiopia. European Scientific Journal, ESJ. 2013 Apr 30;9(10).

[13] Md Saad N. An analysis on the efficiency of takaful and insurance companies in malaysia: a non-parametric approach. Review of Integrative Business \& Economics Research. 2012;1(1):33-56.

[14] Owusu-Ansah E, Dontwi IK, Seidu B, Abudulai G, Sebil C. Technical efficiencies of Ghanaian general insurers. American journal of social and management sciences. 2010;1(1):75-87.

[15] Bawa S, Ruchita R. Efficiencies of health insurance business in India: An application of DEA. American Journal of Social and Management Sciences. 2011;2(2):237-47.

[16] Nandi JK. Relative Efficiency Analysis of Selected Life Insurers in India using Data Envelopment Analysis. Pacific Business Review International. 2014 Feb;6(8):69-76.

[17] Dalkiliç N, Ada AA. Efficiencies of life/pension insurance industry in Turkey: an application of data envelopment analysis. Journal of Applied Finance and Banking. 2014 Jan 1;4(1):181. 